\title{
Olive Stone Delignification Toward Efficient Adsorption of Metal Ions
}

\author{
Ying Gao 1,2, Maria del Carmen Aliques Tomas ${ }^{2}$, Jonas Garemark ${ }^{2}$, Xia Sheng $^{2}$, \\ Lars Berglund ${ }^{2}$ and Yuanyuan $L^{2 *}$ \\ ${ }^{1}$ Co-Innovation Center of Efficient Processing and Utilization of Forest Resources, Nanjing Forestry University, Nanjing, China, \\ ${ }^{2}$ Wallenberg Wood Science Center, Department of Fiber and Polymer Technology, KTH Royal Institute of Technology, Stockholm, \\ Sweden
}

Olive stone is an important biomaterial waste product generated in large amount. As a lignocellulose material, olive stone could be a sustainable resource for biosorbents. In this work, olive stone powder delignification using sodium chlorite $\left(\mathrm{NaClO}_{2}\right)$ was performed to enhance metal ion adsorption capacity. The influence of the treatment on olive stone powder physical-chemical properties was studied, including specific surface area, surface chemistry, morphology, etc. The white, delignified olive stone powder was applied for metal ions $\left(\mathrm{Fe}^{3+}, \mathrm{Cu}^{2+}\right.$, and $\left.\mathrm{Zn}^{2+}\right)$ adsorption. Olive stone delignification not only increases the accessibility of the olive stone powder but also broadens the applications to materials

OPEN ACCESS

Edited by:

David Salinas Torres, University of Alicante, Spain

Reviewed by: Mohammed Ouzzine, Université Sultan Moulay Slimane,

Morocco

Shahla Rezaei,

Tehran University of Medical

Sciences, Iran

*Correspondence:

Yuanyuan $L$

yua@kth.se

Specialty section:

This article was submitted to Mechanics of Materials, a section of the journal Frontiers in Materials

Received: 13 September 2020 Accepted: 08 January 2021 Published: 12 February 2021

Citation:

Gao Y, Aliques Tomas MdelC, Garemark J, Sheng $X$, Berglund $L$ and Li Y (2021) Olive Stone Delignification

Toward Efficient Adsorption of

Metal lons.

Front. Mater. 8:605931.

doi: 10.3389/fmats.2021.605931 design with optical functions by the generation of a white powder.

Keywords: biosorbent, delignification, metal ion, olive stone, white powder

\section{INTRODUCTION}

Improving clean water is a vital part of the sustainable development goals agreed by 195 nations in 2015 (Lozano, 2018). Heavy metal ion contamination of aqueous media from industrial activities is an increasing threat to both the environment and human health. Therefore, removal of heavy metal ions (such as cadmium, copper, iron, lead, nickel, zinc, arsenic etc.) is vital and urgent. Reported techniques to remove heavy metal ions include adsorption, ion exchange, chemical precipitation, electrochemical treatment etc. (Saleem et al., 2019) Among them, bio-adsorption shows a pronounced advantage as a bioremediation of heavy metal ions due to its low cost, high capacity, wide $\mathrm{pH}$ range and the possibility of metal recovery (Gautam et al., 2014).

Olive stone is a lignocellulosic material composed of hemicellulose, cellulose, lignin, as well as appreciable amounts of phenolic compounds and protein (Rodríguez-Gutiérrez et al., 2014). It is one of the most important solid waste products generated from olive oil production. In Spain, approximately 400 thousand tons/year of stone waste was produced from olive oil industries (Rodríguez et al., 2008). Olive stone is usually in the form of small particles due to the crushing operations in the olive oil production process. Normally, olive stones are considered as pollutants, since their disposal creates environmental problems. Meanwhile, the use of waste products from plants for industrial products contributes strongly to the reduction of greenhouse gases (Vera et al., 2020). Compared with forest products, agricultural waste products have lower water consumption footprint (Wong et al., 2016). Therefore, increasing attention is paid to olive stone valorization.

Using olive stone as an adsorbent resource for metal ions in aqueous solutions has been successfully demonstrated (Budinova et al., 2006). The design principles to achieve a good metal ion adsorption capacity include: a high specific surface area and an appropriate surface functionalization for better interaction with metal ions. Carbonization is one approach that generates a high specific surface area, leading to a good adsorption capacity. In a typical process, olive stone is subjected to a high temperature 


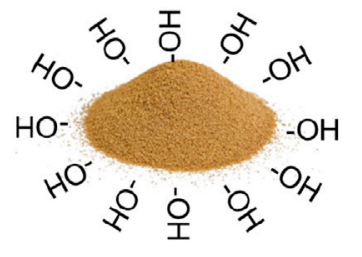

Olive stone powder (OS)
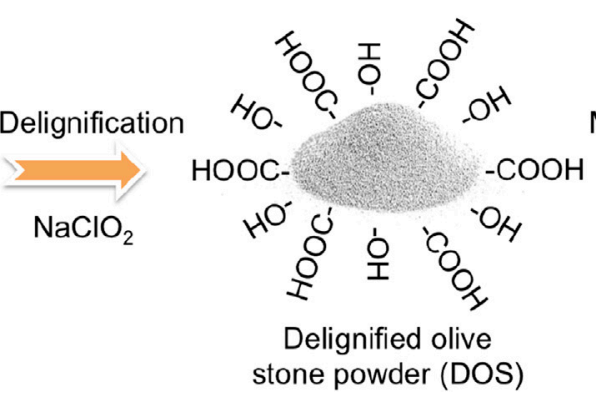

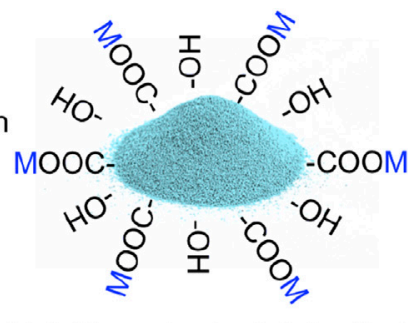

Metal ion adsorbed delignified olive stone powder (DOS-M)

FIGURE 1 | Schematic showing olive stone delignification and the metal ion adsorption process. M represents metal ions.

(normally $300-800^{\circ} \mathrm{C}$ ) in an inert gas atmosphere (includes $\mathrm{N}_{2}$, $\mathrm{CO}_{2}, \mathrm{H}_{2} \mathrm{O}$, etc.). (Aziz et al., 2009b; Blázquez et al., 2014; Jiang et al., 2020). Chemical or physical activations are often included with the aim of improving specific surface area. With this approach, high production cost and low yield (normally less than $50 \mathrm{wt} \%$ ) are restrictions for large-scale production. More information regarding carbonized olive stone based adsorbent can be found in a recent review (Saleem et al., 2019). Another strategy to enhance metal ion adsorption capacity is the introduction of surface functional groups (carboxylic groups, carbonyl groups, sulfonic acid groups, etc.). High concentration acid treatment (De Hoces et al., 2010) and succinic acid grafting (Aziz et al., 2009a) have been reported. However, the safety and corrosive problems associated with concentrated acid and the complex chemical modification process with succinylated olive stone are barriers for further applications.

Delignification is an approach to tune the nanostructure of lignocellulosic materials (such as wood) and to increase their specific surface area (Keplinger et al., 2020). Reported methods include sulfite pulping (Li et al., 2019), acid chlorite bleaching (Li et al., 2018), ionic liquids or deep eutectic solvents treatments (Chen et al., 2019). Among the methods, sodium chlorite $\left(\mathrm{NaClO}_{2}\right)$ delignification is commonly used due to the combination of delignification and bleaching effects (Li et al., 2020). During $\mathrm{NaClO}_{2}$ treatment, lignin aromatic structure undergoes oxidative ring-opening reactions to form acidic groups, the C-2, C-3, or C- 6 of the monomeric sugar units in polysaccharide chains are oxidized to carbonyl or carboxylic groups, which is beneficial for metal ion adsorption ( $\mathrm{Li}$ et al., 2017a). The bleaching effect of $\mathrm{NaClO}_{2}$ treatment could endow the materials design with optical functionalities, such as the fabrication of transparent composites (Li et al., 2016).

In this work, $\mathrm{NaClO}_{2}$ delignification was applied on olive stone powder to increase specific surface area and introduce carboxylic groups. The delignified olive stone powder was further demonstrated for metal ion adsorption with increased adsorption capacity. Figure 1 shows the delignification of olive stone powder and the proposed metal ion adsorption mechanism. In addition, white olive stone powder was obtained. The white olive stone powder makes it possible to reflect color changes due to metal ion adsorption. Furthermore, white olive stone powder fabrication paves the way for applications where light absorption needs to be avoided, such as transparent biocomposites.

\section{EXPERIMENTAL SECTION}

\section{Delignification}

Olive stone powder was provided by BioPowder (Malta) with a particle size of $100-315 \mu \mathrm{m}$ and a moisture content of $9.5 \%$. Delignification was performed according to the literature but with minor changes (Li et al., 2017a). The samples were treated using $\mathrm{NaClO}_{2}$ (Sigma Aldrich) as the reaction agent in an acetate buffer solution $(\mathrm{pH}=4.6)$ at $80^{\circ} \mathrm{C}$ with stirring $(500 \mathrm{rpm})$ until the powder become totally white. $\mathrm{NaClO}_{2}$ concentrations were $3 \mathrm{wt} \%$ and $5 \mathrm{wt} \%$ and the powder concentration varies from 5 to $15 \mathrm{wt} \%$. Detailed parameters variations are shown in Supplementary Table $\mathbf{S 1}$ in the supporting materials. In case that the samples do not turn white in $6 \mathrm{~h}$, a filtration process was carried out and new fresh chemicals were added. After the reaction, the samples were carefully filtrated on a filter $\left(0.65 \mu \mathrm{m}\right.$, Durapore ${ }^{\circledR}$ Membrane Filter) and thoroughly washed with deionized water. This was repeated at least three times for each powder samples. Oven drying process at $105^{\circ} \mathrm{C}$ was carried out to obtain samples for yield calculation, Fourier Transform Infrared Spectroscopy (FTIR), surface charge density, and metal ions adsorption measurements. Liquid $\mathrm{N}_{2}$ freeze-drying process was carried out to obtain samples for Field-Emission Scanning Electron Microscope (FE-SEM), X-Ray Diffraction Analysis (XRD), BET specific surface area and porosity characterizations.

\section{Characterization Methods}

\section{Yield}

The yield of the materials after the reaction was determined according to Eq. 1. $W_{b}$ is the weight of samples before the reaction. $W_{a}$ is the weight of samples after the reaction. The weight of the materials was obtained by weighting the oven-dried samples.

$$
\text { Yield }=\frac{W_{a}}{W_{b}} \times 100 \%
$$

\section{Lignin Content}

The lignin content (Klason lignin) was determined using the TAPPI method TAPPI T222 om-02 (Tappi, 2011). The carbohydrates in original olive powder and delignified olive stone powder were hydrolyzed and solubilized by sulfuric acid (72\%). Then the samples were diluted using distilled water until the concentration of sulfuric acid was $3 \%$. After that the samples 
were placed in an autoclave for $60 \mathrm{~min}$ at $125^{\circ} \mathrm{C}$. Then all the samples were filtered under vacuum through fiber glass filter. The acid-insoluble lignin was filtered off, dried, and weighed. Three parallel measurements were done to get the data.

\section{BET Specific Surface Area and Porosity}

The BET specific surface area was evaluated by $\mathrm{N}_{2}$ physisorption. The experiment was carried out on a Micrometrics, ASAP 2020. Prior to the $\mathrm{N}_{2}$ adsorption, the samples were degassed at $90^{\circ} \mathrm{C}$ for 2 days. The analysis of the materials was obtained after carrying out measurements of $\mathrm{N}_{2}$ adsorption-desorption isotherms at liquefaction temperature $\left(196^{\circ} \mathrm{C}\right)$ under relative vapor pressure of $0.05-0.25$. The BET specific surface area was then calculated from the attained isotherms.

\section{Field-Emission Scanning Electron Microscope}

FE-SEM (Hitachi S-4800 Japan) was applied to obtain the morphological information of the materials. The dried samples were coated with platinum-palladium using a sputter coater (Cressington 208HR, United Kingdom) before performing the FE-SEM analysis. During the characterization, the accelerating voltage was set at $1 \mathrm{kV}$.

\section{Fourier Transform Infrared Spectroscopy}

FTIR analysis was performed using a FTIR spectrometer (Spectrum 100/Spotlight 400, PekinElmer, Norwalk, CT). FTIR spectra were recorded between a wavelength of 600 and $4,000 \mathrm{~cm}^{-1}$. The spectrum was processed through PerkinElmer Spectrum software.

\section{X-Ray Diffraction Analysis (XRD)}

XRD was performed in a powder diffractometer (Thermo Fisher Scientific ARL X'TRA powder diffractometer). CuKa radiation $(\lambda=1.54060 \AA)$ at $40 \mathrm{~mA}$ and $45 \mathrm{kV}$ was applied. The program has a scan interval of $5^{\circ}<2 \theta<50^{\circ}$, with a step size of $0.04^{\circ}(2 \theta)$. The crystallinity index (CrI) was calculated with peak height method according to Eq. 2. $\mathrm{I}_{200}$ is the intensity of the [200] crystalline peak and $\mathrm{I}_{\text {Amorphous }}$ is the intensity of amorphous peak.

$$
C r I=\frac{I_{200}-I_{\text {Amorphous }}}{I_{200}} \times 100 \%
$$

\section{Charge Density}

The change of surface charge density of olive stone powder was measured by conductive titration (856 Conductimeter Module, Metrohm). The olive stone powder was first protonated using $\mathrm{HCl}(0.1 \mathrm{M}, 5 \mathrm{ml})$. Then titration was performed using $\mathrm{NaOH}$ $(0.05 \mathrm{M})$. When the conductance decreased till the equivalence point, the charge density was calculated according to the $\mathrm{NaOH}$ consumption.

\section{Metal Ions Adsorption Test}

$\mathrm{Fe}^{3+}, \mathrm{Cu}^{2+}$ and $\mathrm{Zn}^{2+}$ are often found in the effluents from industries (electroplating company, pulp and paper company, etc.). High concentration of $\mathrm{Fe}^{3+}, \mathrm{Cu}^{2+}$ or $\mathrm{Zn}^{2+}$ in water is a threat to both the environment and human health. Therefore, $\mathrm{Fe}^{3+}, \mathrm{Cu}^{2+}$ and $\mathrm{Zn}^{2+}$ are used for metal ion adsorption test. Dissolving appropriate amounts of $\mathrm{FeCl}_{3} \cdot 6 \mathrm{H}_{2} \mathrm{O}$ (s, Sigma Aldrich), $\mathrm{CuCl}_{2} \cdot 2 \mathrm{H}_{2} \mathrm{O}$ (s, Sigma Aldrich) and $\mathrm{ZnCl}_{2}$ (s, Sigma Aldrich) in deionized water to prepare approximately $100 \mathrm{mg} / \mathrm{L}$ stock solution of salts separately. Then diluted the stock solution to $80 \mathrm{mg} / \mathrm{L}$ (salt concentration) to prepare experimental solution of $\mathrm{Fe}^{3+}, \mathrm{Cu}^{2+}$, and $\mathrm{Zn}^{2+}$. The metal ion adsorption test was performed according to the literature with minor changes (Alslaibi et al., 2014a). In brief, metal ions adsorption was studied by agitating $250 \mathrm{ml}$ of $80 \mathrm{mg} / \mathrm{L}$ experimental solution of $\mathrm{Fe}^{3+}, \mathrm{Cu}^{2+}$, and $\mathrm{Zn}^{2+}$ with $0.5 \mathrm{~g}$ olive stone under vigorous stirring at $\mathrm{pH} 4.5$ for $2.5 \mathrm{~h}$ until it reached equilibrium. All the $\mathrm{pH}$ measurements were conducted using a $\mathrm{pH}$ meter (Mettler-Toledo AG 8603). The initial $\mathrm{pH}$ levels of the experimental solutions were adjusted using $0.1 \mathrm{M}$ solution of $\mathrm{HCl}$ and $\mathrm{NaOH}$. After stirring, the solid was removed by filtration through a $0.2 \mu \mathrm{m}$ pore size filter paper. The final metal concentration in the filtrate as well as in the initial solution was determined using Inductively Coupled Plasma Optical Emission Spectrometer (ICP-OES, iCAP 6,000, Thermo Fisher Scientific). The sobbed metal concentrations were obtained from the difference between the initial and final metal concentrations in solution. The amount of adsorption of metal ions was calculated using Eq. 3:

$$
\text { Adsorption capacity }=\frac{\left(C_{0}-C_{1}\right) V}{W}
$$

$C_{0}$ and $C_{1}(\mathrm{mg} / \mathrm{L})$ are the ion concentrations of $\mathrm{Fe}^{3+}, \mathrm{Cu}^{2+}$, and $\mathrm{Zn}^{2+}$ at the initial and after absorbed by olive stone powder, respectively; $V(\mathrm{~L})$ is the volume of solution; and $W(\mathrm{~g})$ is the weight of dry olive stone powder.

\section{RESULTS AND DISCUSSION}

\section{Characterization of the Delignified Olive Stone Powder}

Lignin accounts for around 23.1 to $40.4 \mathrm{wt} \%$ of olive stone (De Hoces et al., 2010; Rodríguez et al., 2008) Removing lignin could improve the specific surface area and accessibility of olive stone powder. In addition, lignin is a main contributor to the brown color of lignocellulose materials (Li et al., 2017b). Delignification using $\mathrm{NaClO}_{2}$ is an industrially established approach to remove lignin and bleach woody materials (Li et al., 2016). In this work, $\mathrm{NaClO}_{2}$ based delignification was applied to treat olive stone powder. Parameter optimization was done first to obtain white olive stone powder with the aim of a high yield and high surface charge. Supplementary Table S2 in supporting information shows the yield and reaction time for delignification process with various $\mathrm{NaClO}_{2}$ and powder concentrations. With $5 \mathrm{wt} \%$ $\mathrm{NaClO}_{2}$ and powder concentration of $15 \mathrm{wt} \%$, a relative high yield of $66.9 \mathrm{wt} \%$ was obtained. The weight loss is mainly due to the removal of lignin as well as partial degradation of hemicellulose and cellulose. A significant increase in surface charge was detected after delignification (Table $\mathbf{1}$ and Supplementary Table S3). The surface charge of OS is $47 \mu \mathrm{eq} / \mathrm{g}$, while the value is $364 \mu \mathrm{eq} / \mathrm{g}$ for DOS with $3 \mathrm{wt} \% \mathrm{NaClO}_{2}$ treatment 
TABLE 1 | Lignin content, surface charge, BET specific surface area (BET SSA) and crystallinity index (Crl) of original olive stone powder (OS) and delignified olive stone powder (DOS).

\begin{tabular}{lcccc}
\hline & $\begin{array}{c}\text { Lignin content } \\
(\mathbf{w t} \%)\end{array}$ & $\begin{array}{c}\text { Surface charge* } \\
(\boldsymbol{\mu e q} / \mathbf{g})\end{array}$ & $\begin{array}{c}\text { BET SSA* } \\
\left(\mathbf{m}^{\mathbf{2}} / \mathbf{g}\right)\end{array}$ & $\begin{array}{c}\text { Crl } \\
\mathbf{( \% )}\end{array}$ \\
\hline OS & 29.4 & 47 & 0.44 & 66 \\
DOS & 3.1 & 665 & 1.52 & 74
\end{tabular}

* Represents the properties that show significant difference between OS and DOS. The data reported are average data based on three parallel measurements.

and $665 \mu \mathrm{eq} / \mathrm{g}$ for DOS with $5 \mathrm{wt} \% \mathrm{NaClO}_{2}$ treatment. The increased surface charge is beneficial for metal ion adsorption. Considering the high yield and surface charge, the delignified samples used in the following are obtained with $\mathrm{NaClO}_{2}$ concentration of $5 \mathrm{wt} \%$, powder concentration of $15 \mathrm{wt} \%$ at a delignification temperature of $80^{\circ} \mathrm{C}$.

The olive stone powder is light brown initially with a powder size of 100-315 $\mu \mathrm{m}$ (Figure 2A). The particles are bundles of elongated cells as shown in Figure 2B. A rough and dense surface is detectable. There are plasmodesma structures for interconnection between adjacent cells (Figure 2C). After delignification, the olive stone powder becomes white as shown in Figure 2D. Lignin content was changed from $29.4 \mathrm{wt} \%$ for original olive stone to $3.1 \mathrm{wt} \%$ for delignified olive stone (Table 1). Around $90 \%$ of the lignin was thus eliminated after the treatment. In Figures 2D, E, most of the cells are separated from cell aggregates, leading to a decreased particle size (normally less than $100 \mu \mathrm{m}$ ). There are layers of cell materials peeling off from the particles, which can be seen form Figure 2E and Supplementary Figure S1 in supporting information. Fibril structures are apparent on the edge of the particles (Figure 2F). The decreased particle size, peeling off of the cell wall as well as the fibril structures generated all contribute to an increased specific surface area. At the same time, EDX mapping showed that DOS sample has $\mathrm{C}, \mathrm{O}, \mathrm{Na}, \mathrm{Cl}$ and $\mathrm{Pt}$ elements after delignification while $\mathrm{OS}$ only has $\mathrm{C}, \mathrm{O}$ and $\mathrm{Pt}$ elements (Supplementary Figure S3). The Pt in both samples was derived from coating, and the trace amount of $\mathrm{Na}$ and $\mathrm{Cl}$ inside DOS came from the salts used in the delignification process.

FTIR was applied to monitor the chemical structure change after delignification (Figure 2G). The peak at $1732 \mathrm{~cm}^{-1}$ and $2906 \mathrm{~cm}^{-1}$ are assigned to the stretching vibration of the carbonyl group. The broadening and intensity increase of
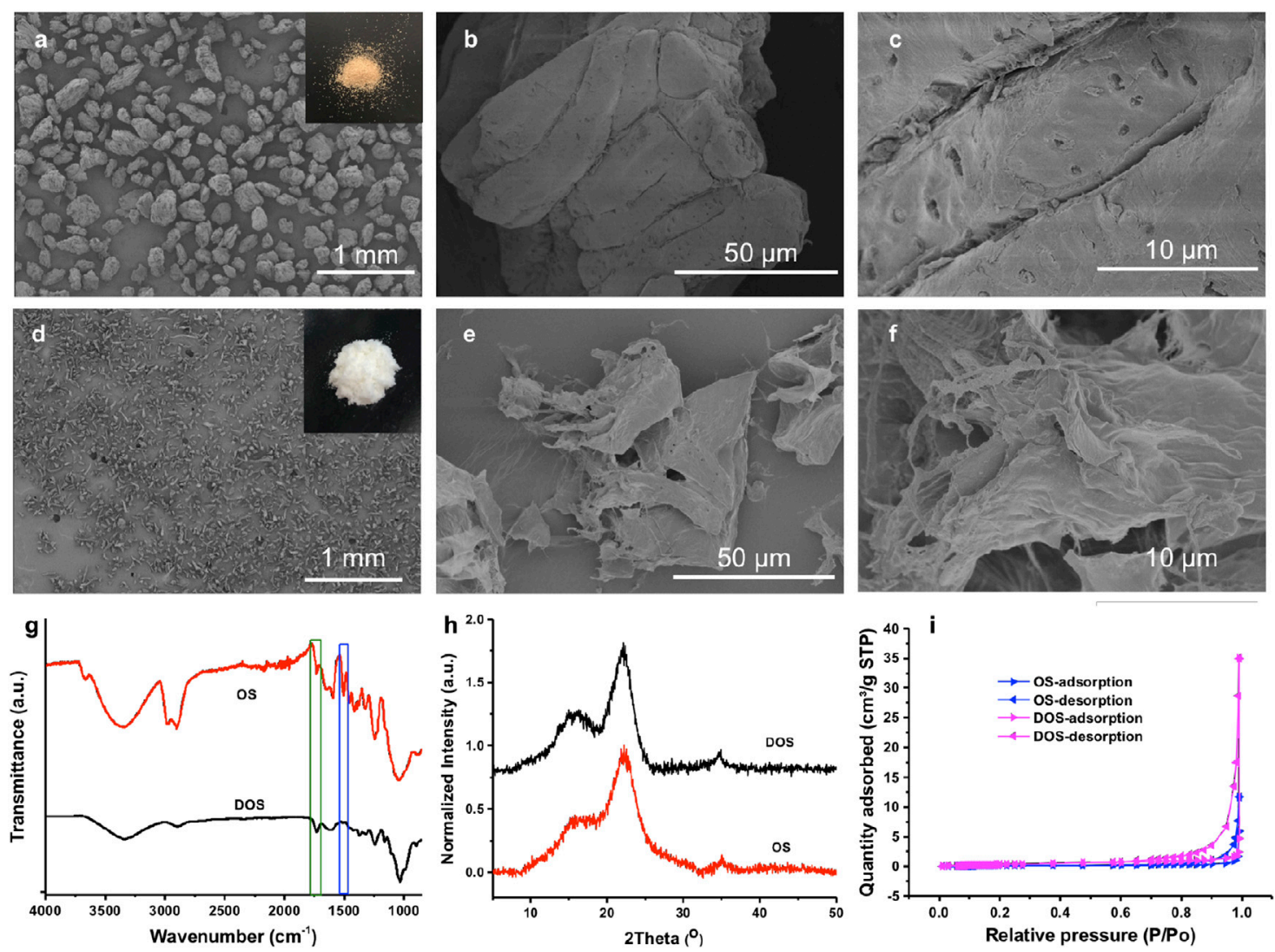

FIGURE 2 I SEM images of original olive stone powder (A-C), and delignified olive stone powder (D-F). Inset images in (A) and (D) are photos of original stone powder and delignified olive stone powder respectively. (G-I) are the FIIR spectra, XRD spectra, and nitrogen adsorption-desorption isotherms of original olive stone powder (OS) and delignified olive stone powder (DOS) respectively. 


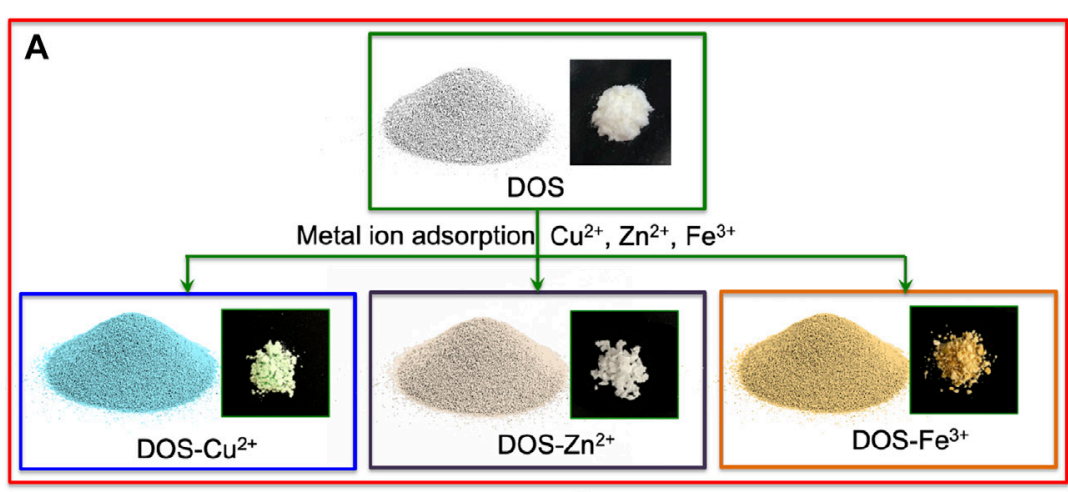

B

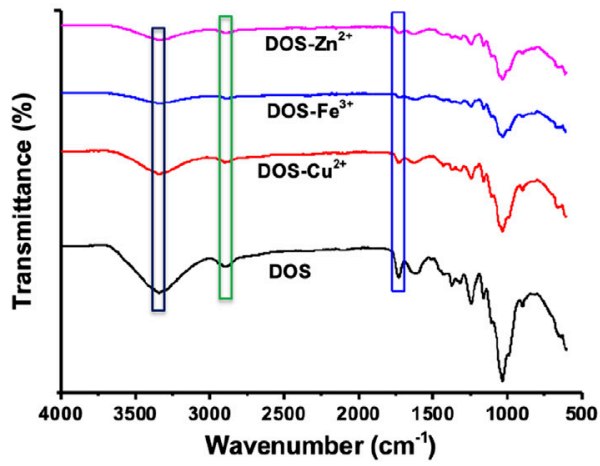

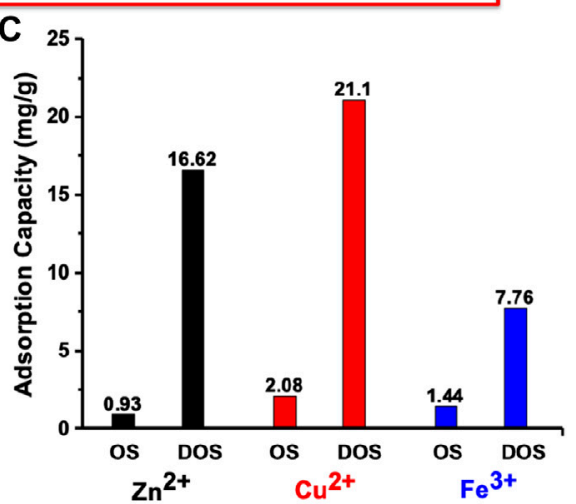

FIGURE 3 | (A) illustrates color change of delignified olive stone powder after differences in metal ion adsorption. (B) FTIR spectra of delignified olive stone powder after adsorption of $\mathrm{Fe}^{3+}, \mathrm{Cu}^{2+}$, and $\mathrm{Zn}^{2+}$. (C) metal ion absorption of original olive stone powder (OS) and delignified olive stone powder (DOS) for different metal ions.

the peak at $1732 \mathrm{~cm}^{-1}$ indicates the introduction of carbonyl groups in the delignified olive stone powder. This was mainly due to the generation of carboxylic groups during the treatment. This was further supported by the increased surface charge from $47 \mu \mathrm{eq} / \mathrm{g}$ for original olive stone powder to $665 \mu \mathrm{eq} / \mathrm{g}$ for delignified olive stone powder. The peak at around $1500 \mathrm{~cm}^{-1}$ is assigned to aromatic rings, a characteristic peak for lignin. The peak disappears after delignification, in support of lignin removal.

Both original olive stone powder and delignified olive stone powder show the same cellulose crystal structure. Figure $\mathbf{2 H}$ shows the relative XRD spectra. The peaks at $22.6^{\circ}$, between $14.5^{\circ}$ and $16.5^{\circ}$, and around $34^{\circ}$, correspond to the presence of cellulose I in the materials. With peak intensity method, the crystallnity index (CrI) is $66 \%$ for original olive stone powder and $74 \%$ for delignified olive stone powder (Table 1). This increase in CrI is mainly due to the removal of lignin and hemicellulose, which are considered as amorphous components.

A high specific surface area is preferred for a high metal ion adsorption capacity. BET SSA was obtained through physisorption measurements of $\mathrm{N}_{2}$ on powders. Figure 2I shows the $\mathrm{N}_{2}$ adsorption-desorption isotherms. In both graphs, a hysteresis cycle is observed, a characteristic aspect of type $\mathrm{V}$ isotherms. The BET SSA of delignified olive stone powder is $1.52 \mathrm{~m}^{2} / \mathrm{g}$, lager than that of original olive stone powder $\left(0.44 \mathrm{~m}^{2} / \mathrm{g}\right)$. The pore volume is $0.000530 \mathrm{~cm}^{3} / \mathrm{g}$ for DOS, higher than that of OS $\left(0.000187 \mathrm{~cm}^{3} / \mathrm{g}\right)$. One reason for the difference is that, lignin, some hemicellulose and cellulose are eliminated (around $33.1 \%$ weight loss), leading to the formation of pores and increased surface area. In addition, decreased particle size and fibril structures contribute to increased specific surface area.

\section{Metal Ion Adsorption Test}

The adsorption of $\mathrm{Fe}^{3+}, \mathrm{Cu}^{2+}$, and $\mathrm{Zn}^{2+}$ were demonstrated by batch technique under $\mathrm{pH}$ of 4.5. The powder color changed after metal ion adsorption. Photos of the olive stone powders are shown in Figure 3A. The white powder became light blue after $\mathrm{Cu}^{2+}$ adsorption and became light yellow after $\mathrm{Fe}^{3+}$ adsorption. It remains colorless after $\mathrm{Zn}^{2+}$ adsorption. This is an advantage of delignified olive stone powder that adsorption of specific metal ions could be reflected through color change. For carbonized black powders or brown original olive stone powder with lignin, the metal ion color change is not apparent after adsorption. In addition, the difference between a low concentration metal ions adsorption and a high concentration adsorption is visually apparent by color differences. The sample with a high $\mathrm{Cu}^{2+}$ concentration is dark blue, while the sample with a low $\mathrm{Cu}^{2+}$ concentration is light blue (Supplementary Figure S2 in the supporting information).

The hypothesis for metal ion adsorption mechanisms on DOS powder is the ion exchange of the metal ion with the $\mathrm{H}^{+}$in the carboxylic groups. FTIR spectra reflect the exchange between 
metal ion and carboxylic groups (Figure 3B). The decreased peak intensities at $1732 \mathrm{~cm}^{-1}$ and $2,906 \mathrm{~cm}^{-1}$ are due to the decrease of carboxylic group stretch dimer $\mathrm{H}$-bonded. These peaks and bands prove the presence of the hydroxyl group and the carboxylic groups of cellulose and hemicellulose in the biosorbent, which are responsible for the metal adsorption. The broad band that appeared at $3338 \mathrm{~cm}^{-1}$ is characteristic stretching vibration of the hydroxyl group due to hydrogen bonding $\mathrm{O}-\mathrm{H}$ to a carboxyl, phenol or alcohol group. The results of the adsorbent before and after adsorption were compared. There are significant changes in peaks at $3338 \mathrm{~cm}^{-1}, 2906 \mathrm{~cm}^{-1}$ and $1732 \mathrm{~cm}^{-1}$. These red shifts indicate that the hydroxyl and carboxyl groups are involved in the adsorption of the metals (Parthasarathy and Narayanan, 2014).

A high metal ion adsorption capacity is required for real applications. In this work, the adsorption capacity of delignified olive stone powder is $7.76 \mathrm{mg} / \mathrm{g}$ for $\mathrm{Fe}^{3+}, 21.1 \mathrm{mg} / \mathrm{g}$ for $\mathrm{Cu}^{2+}$, and $16.62 \mathrm{mg} / \mathrm{g}$ for $\mathrm{Zn}^{2+}$ respectively (Figure 3C). These values are much higher than that of original olive stone powder with a capacity of $1.44 \mathrm{mg} / \mathrm{g}$ for $\mathrm{Fe}^{3+}, 2.08 \mathrm{mg} / \mathrm{g}$ for $\mathrm{Cu}^{2+}$, and $0.93 \mathrm{mg} / \mathrm{g}$ for $\mathrm{Zn}^{2+}$. The values are among the highest adsorption data reported in the literature(Alslaibi et al., 2013; Hodaifa et al., 2014; Bohli et al., 2015; Amar et al., 2020). Supplementary Table S4 in the supporting information is the summary of the olive stone based adsorbents for $\mathrm{Fe}^{3+}$, $\mathrm{Cu}^{2+}$, and $\mathrm{Zn}^{2+}$ adsorption(Alslaibi et al., 2014a), (Bohli et al., 2015), (Amar et al., 2020), (Galiatsatou et al., 2002; Alslaibi et al., 2014b; Bohli and Ouederni, 2016; Bohli et al., 2017; Fernández-González et al., 2018, Fernández-González et al., 2020). A high adsorption capacity is usually realized through carbonization combined with proper activation (Supplementary Table S4). With carbonization, the yield is low (less than 50\%), embodied energy of the powder increased and the process cost is strongly increased. With delignification, the yield is high (normally higher than 50\%) and the treatment process is easy to be scaled up at a low cost. Meanwhile, the delignified olive stone powder can desorb metal ions easily by the use of strong acid. After addition of $2 \mathrm{M} \mathrm{HCl}$ into $\mathrm{Cu}^{2+}$ adsorbed samples followed by stirring for $1 \mathrm{~h}$, the sample released $\mathrm{Cu}^{2+}$ into the water again and returned to white appearance. This demonstrates the possibility to recycle the olive stone powder as a metal ion adsorbent.

\section{CONCLUSION}

Delignification was applied to olive stone powder resulting in a high surface charge due to introduction of carboxylic groups and an increased specific surface area mainly ascribing to the lignin removal, decreased particle size as well as fibril structure generation. Delignified olive stone powder was further applied for metal ion adsorption showing an improved adsorption capacity. The adsorption capacities are $7.76 \mathrm{mg} / \mathrm{g}$ for $\mathrm{Fe}^{3+}$, $21.1 \mathrm{mg} / \mathrm{g}$ for $\mathrm{Cu}^{2+}$, and $16.62 \mathrm{mg} / \mathrm{g}$ for $\mathrm{Zn}^{2+}$ respectively, which are among the highest values in the literature. The method is scalable with a relatively low cost. In addition, delignification results in white olive stone powder. This broadens the applications of olive stone powders with optical functionalities such as transparent composites. There is a green perspective to use agricultural waste products, such as olive stone powder.

\section{DATA AVAILABILITY STATEMENT}

The original contributions presented in the study are included in the article/Supplementary Material, further inquiries can be directed to the corresponding author.

\section{AUTHOR CONTRIBUTIONS}

YG did the experiments, analyzed data, and wrote the manuscript. MT did part of the experiments and wrote part of the manuscript. JG did the XRD and BET measurements. XS did the surface charge and FTIR characterization. YL conceived the idea, designed the experiments, and supervised the work. LB conceived the idea and supervised the work. All authors provided critical feedback and edited the manuscript.

\section{FUNDING}

This project has received funding from the European Research Council (ERC) under the European Union's Horizon 2020 research and innovation program (Grant Agreement No. 742733) at KTH Royal Institute of Technology and the funding from Vetenskapsrådet (VR, No. 2017-05349). YG acknowledges financial support from project funded by the National First-class Disciplines (PNFD) and the Priority Academic Program Development of Jiangsu Higher Education Institutions (PAPD).

\section{ACKNOWLEDGMENTS}

The company, BioPowder, was acknowledged for supplying the olive stone powder. Hui Chen and Xuan Yang are acknowledged for the help in the lignin content measurements. Yi Yang is acknowledged for the help of metal ions concentration test.

\section{SUPPLEMENTARY MATERIAL}

The Supplementary Material for this article can be found online at: https://www.frontiersin.org/articles/10.3389/fmats.2021.605931/ full\#supplementary-material. 


\section{REFERENCES}

Alslaibi, T. M., Abustan, I., Ahmad, M. A., and Abu Foul, A. (2014a). Comparison of activated carbon prepared from olive stones by microwave and conventional heating for iron (II), lead (II), and copper (II) removal from synthetic wastewater. Environ. Prog. Sustain. Energy. 33 (4), 1074-1085. doi:10.1002/ep.11877

Alslaibi, T. M., Abustan, I., Ahmad, M. A., and Abu Foul, A. (2014b). Preparation of activated carbon from olive stone waste: optimization study on the removal of $\mathrm{Cu} 2+, \mathrm{Cd} 2+, \mathrm{Ni2}+, \mathrm{Pb} 2+, \mathrm{Fe} 2+$, and $\mathrm{Zn} 2+$ from aqueous solution using response surface methodology. J. Dispersion Sci. Technol. 35 (7), 913-925. doi:10.1080/01932691.2013.809506

Alslaibi, T. M., Abustan, I., Ahmad, M. A., and Foul, A. A. (2013). Application of response surface methodology (RSM) for optimization of $\mathrm{Cu} 2+, \mathrm{Cd} 2+, \mathrm{Ni2}+$, $\mathrm{Pb} 2+, \mathrm{Fe} 2+$, and $\mathrm{Zn} 2+$ removal from aqueous solution using microwaved olive stone activated carbon. J. Chem. Technol. Biotechnol. 88 (12), 2141-2151. doi: $10.1002 /$ jctb.4073

Amar, M. B., Walha, K., and Salvadó, V. (2020). Evaluation of olive stones for $\mathrm{Cd}(\mathrm{II}), \mathrm{Cu}(\mathrm{II}), \mathrm{Pb}(\mathrm{II})$ and $\mathrm{Cr}(\mathrm{VI})$ biosorption from aqueous solution: equilibrium and kinetics. Int. J. Environ. Res. 14 (2), 193-204. doi:10.1007/ s41742-020-00246-5

Aziz, A., Elandaloussi, el. H., Belhalfaoui, B., Ouali, M. S., and De Ménorval, L. C. (2009a). Efficiency of succinylated-olive stone biosorbent on the removal of cadmium ions from aqueous solutions. Colloids Surf. B Biointerfaces 73 (2), 192-198. doi:10.1016/j.colsurfb.2009.05.017

Aziz, A., Ouali, M. S., Elandaloussi, el. H., De Menorval, L. C., and Lindheimer, M. (2009b). Chemically modified olive stone: a low-cost sorbent for heavy metals and basic dyes removal from aqueous solutions. J. Hazard Mater. 163 (1), 441-447. doi:10.1016/j.jhazmat.2008.06.117

Blázquez, G., Calero, M., Ronda, A., Tenorio, G., and Martín-Lara, M. A. (2014). Study of kinetics in the biosorption of lead onto native and chemically treated olive stone. J. Ind. Eng. Chem. 20 (5), 2754-2760. doi:10.1016/j.jiec.2013.11.003

Bohli, T., and Ouederni, A. (2016). Improvement of oxygen-containing functional groups on olive stones activated carbon by ozone and nitric acid for heavy metals removal from aqueous phase. Environ. Sci. Pollut. Res. Int. 23 (16), 15852-15861. doi:10.1007/s11356-015-4330-0

Bohli, T., Ouederni, A., Fiol, N., and Villaescusa, I. (2015). Evaluation of an activated carbon from olive stones used as an adsorbent for heavy metal removal from aqueous phases. Compt. Rendus Chem. 18 (1), 88-99. doi:10. 1016/j.crci.2014.05.009

Bohli, T., Ouederni, A., and Villaescusa, I. (2017). Simultaneous adsorption behavior of heavy metals onto microporous olive stones activated carbon: analysis of metal interactions. Euro-Mediterranean J. Environ. Integr. 2 (1), 1-15. doi:10.1007/s41207-017-0030-0

Budinova, T., Petrov, N., Razvigorova, M., Parra, J., and Galiatsatou, P. (2006). Removal of arsenic(III) from aqueous solution by activated carbons prepared from solvent extracted olive pulp and olive stones. Ind. Eng. Chem. Res. 45 (6), 1896-1901. doi:10.1021/ie051217a

Chen, Z., Dang, B., Luo, X., Li, W., Li, J., Yu, H., et al. (2019). Deep eutectic solventassisted in Situ wood delignification: a promising strategy to enhance the efficiency of wood-based solar steam generation devices. ACS Appl. Mater. Interfaces. 11 (29), 26032-26037. doi:10.1021/acsami.9b08244

De Hoces, M. C., Blázquez García, G., Gálvez, A. R., and Martín-Lara, M. Á. (2010). Effect of the acid treatment of olive stone on the biosorption of lead in a packedbed column. Ind. Eng. Chem. Res. 49 (24), 12587-12595. doi:10.1021/ie1013597

Fernández-González, R., Martín-Lara, M. A., Blázquez, G., Tenorio, G., and Calero, M. (2020). Hydrolyzed olive cake as novel adsorbent for copper removal from fertilizer industry wastewater. J. Clean. Prod. 268, 121935. doi:10.1016/j.jclepro.2020.121935

Fernández-González, R., Martín-Lara, M. A., Iáñez-Rodríguez, I., and Calero, M. (2018). Removal of heavy metals from acid mining effluents by hydrolyzed olive cake. Bioresour. Technol. 268, 169-175. doi:10.1016/j.biortech.2018.07.124

Galiatsatou, P., Metaxas, M., and Kasselouri-Rigopoulou, V. (2002). Adsorption of zinc by activated carbons prepared from solvent extracted olive pulp. J. Hazard Mater. 91 (1-3), 187-203. doi:10.1016/s0304-3894(02)00008-0

Gautam, R. K., Mudhoo, A., Lofrano, G., and Chattopadhyaya, M. C. (2014). Biomass-derived biosorbents for metal ions sequestration: adsorbent modification and activation methods and adsorbent regeneration. J. Environ. Chem. Eng. 2 (1), 239-259. doi:10.1016/j.jece.2013.12.019
Hodaifa, G., Alami, S. B. D., Ochando-Pulido, J. M., and Víctor-Ortega, M. D. (2014). Iron removal from liquid effluents by olive stones on adsorption column: breakthrough curves. Ecol. Eng. 73, 270-275. doi:10.1016/j.ecoleng.2014.09.049

Jiang, J., Carrillo-Enríquez, N., Oguzlu, H., Han, X., Bi, R., Saddler, J., et al. (2020). Acidic deep eutectic solvent assisted isolation of lignin containing nanocellulose from thermomechanical pulp. Carbohydr. Polym. 247, 116727. doi:10.1016/j. carbpol.2020.116727

Keplinger, T., Wittel, F. K., Rüggeberg, M., and Burgert, I. (2020). Wood derived cellulose scaffolds-processing and Mechanics. Adv. Mater., e2001375. doi:10. 1002/adma.202001375

Li, K., Wang, S., Chen, H., Yang, X., Berglund, L. A., and Zhou, Q. (2020). Selfdensification of highly mesoporous wood structure into a strong and transparent film. Adv. Mater. 32 (42), e2003653. doi:10.1002/adma.202003653

Li, T., Zhai, Y., He, S., Gan, W., Wei, Z., Heidarinejad, M., et al. 2019). A radiative cooling structural material. Science 364 (6442), 760-763. doi:10.1126/science. aau 9101

Li, Y., Fu, Q., Rojas, R., Yan, M., Lawoko, M., and Berglund, L. (2017a). Ligninretaining transparent wood. ChemSusChem. 10 (17), 3445-3451. doi:10.1002/ cssc. 201701089

Li, Y., Yang, X., Fu, Q., Rojas, R., Yan, M., and Berglund, L. A. (2017b). Towards centimeter thick transparent wood through interface manipulation. J. Mater. Chem. 6 (3), 1094-1101. doi:10.1039/C7TA09973H

Li, Y., Fu, Q., Yu, S., Yan, M., and Berglund, L. (2016). Optically transparent wood from a nanoporous cellulosic template: combining functional and structural performance. Biomacromolecules 17 (4), 1358-1364. doi:10.1021/acs.biomac. $6 \mathrm{~b} 00145$

Li, Y., Yang, X., Fu, Q., Rojas, R., Yan, M., and Berglund, L. (2018). Towards centimeter thick transparent wood through interface manipulation. J. Mater. Chem. 6 (3), 1094-1101. doi:10.1039/c7ta09973h

Lozano, R. (2018). Measuring progress from 1990 to 2017 and projecting attainment to 2030 of the health-related Sustainable Development Goals for 195 countries and territories: a systematic analysis for the Global Burden of Disease Study 2017. Lancet 392 (10159), 2091-2138. doi:10.1016/S01406736(18)32281-5

Parthasarathy, P., and Narayanan, S. K. (2014). Effect of hydrothermal carbonization reaction parameters on. Environ. Prog. Sustain. Energy 33, 676-680.

Rodríguez, G., Lama, A., Rodríguez, R., Jiménez, A., Guillén, R., and FernándezBolaños, J. (2008). Olive stone an attractive source of bioactive and valuable compounds. Bioresour. Technol. 99 (13), 5261-5269. doi:10.1016/j.biortech. 2007.11.027

Rodríguez-Gutiérrez, G., Rubio-Senent, F., Lama-Muñoz, A., García, A., and Fernández-Bolaños, J. (2014). Properties of lignin, cellulose, and hemicelluloses isolated from olive cake and olive stones: binding of water, oil, bile acids, and glucose. J. Agric. Food Chem. 62 (36), 8973-8981. doi:10. 1021/jf502062b

Saleem, J., Shahid, U. B., Hijab, M., Mackey, H., and McKay, G. (2019). Production and applications of activated carbons as adsorbents from olive stones. Biomass Conv. Bioref. 9 (4), 775-802. doi:10.1007/s13399-019-00473-7

Tappi (2011). Lignin in wood and pulp, T222 om-02, 1-7.

Vera, I., Hoefnagels, R., Kooij, A., Moretti, C., and Junginger, M. (2020). A carbon footprint assessment of multi-output biorefineries with international biomass supply: a case study for The Netherlands. Biofuels. Bioprod. Bioref. 14 (2), 198-224. doi:10.1002/bbb.2052

Wong, A., Zhang, H., and Kumar, A. (2016). Life cycle water footprint of hydrogenation-derived renewable diesel production from lignocellulosic biomass. Water Res. 102, 330-345. doi:10.1016/j.watres.2016.06.045

Conflict of Interest: The authors declare that the research was conducted in the absence of any commercial or financial relationships that could be construed as a potential conflict of interest.

Copyright $\odot 2021$ Gao, Aliques Tomas, Garemark, Sheng, Berglund and Li. This is an open-access article distributed under the terms of the Creative Commons Attribution License (CC BY). The use, distribution or reproduction in other forums is permitted, provided the original author(s) and the copyright owner $(s)$ are credited and that the original publication in this journal is cited, in accordance with accepted academic practice. No use, distribution or reproduction is permitted which does not comply with these terms. 